\title{
CHAPTER ELEVEN
}

\section{S. Naipaul}

\author{
Sue Thomas
}

Vidiadhur Surajprasad Naipaul's narratives of arrival in England return repeatedly to his father Seepersad's nurturing of his artistic ambition in Trinidad, and his early prescience that the 'idea of the writing vocation' given him by a colonial acculturation could be realised and practised in England. ${ }^{1}$ In making himself a writer, ${ }^{2}$ he has abjured being categorised as West Indian, most famously in withdrawing the manuscript of Guerillas (1975) from publisher Secker and Warburg after being described in a catalogue as 'the West Indian novelist'. ${ }^{3}$ His career as a determinedly 'extraregional' writer of fiction, travel books and memoir ${ }^{4}$ has been both stellar and controversial. In 1990 he was awarded Trinidad's Trinity Cross and knighted by British monarch Elizabeth II. The biographical note in his latest novel Half a Life (2001) rather acerbically states that ' $[\mathrm{h}] \mathrm{e}$ has won every major literary award bar the Nobel'. ${ }^{5}$ Cited by the Swedish Academy as a 'British writer, born in Trinidad', he finally did win the Nobel Prize for Literature in 2001 'for having united perceptive narrative and incorruptible scrutiny in works that compel us to see the presence of suppressed histories ... Naipaul is Conrad's heir as the annalist of the destinies of empires in the moral sense: what they do to human beings. His authority as a narrator is grounded in the memory of what others have forgotten, the history of the vanquished'. ${ }^{6}$ Naipaul's work is praised here as being faithful to history and a historical constituency of the oppressed, his interpretation of them being motivated by moral rigour and truth, rather than by cultural and artistic values which have ideological and political groundings. Given the controversies generated by his writing and his public persona the claim is extraordinary. His stances on and representations of the politics of decolonisation are frequently denounced as reactionary. Edward Said, for instance, has decried Naipaul as 'immoral', a pedlar of 'the tritest, the cheapest and the easiest of colonial mythologies about wogs and darkies' and comforting 


\section{S. NAIPAUL}

imperialist theses concerning the 'self-inflicted wounds' of the colonised. ${ }^{7}$ The relation of Naipaul and his work to the post-imperial encounter in Britain is, however, more complicated than such denunciations suggest. Exacting anxieties have haunted his witness of his journey from the 'exotic' periphery to the centre of English culture through the practice of a vocation he idealises and conceptualises with such rigid conservatism.

\section{Negotiating the periphery}

In 1958, on the eve of the Notting Hill riots, Naipaul saw himself as an 'exotic writer', 'liv[ing] in England and depend[ing] on an English audience' ${ }^{8}$ Born in Chaguanas in 1932, Naipaul had arrived in England in 1950 to study English at Oxford University, after a long period in Port of Spain 'spent in a blind, driven kind of colonial studying' to win his scholarship. ${ }^{9}$ Explaining his decision not to return to Trinidad to his mother Droapati in 1954, he writes: 'The place is too small, the values are all wrong, and the people are petty ... This country [England] is hot with racial prejudices, and I certainly don't wish to stay here. ${ }^{10} \mathrm{He}$ was then in the process of identifying his early subject matter: social comedies set in Trinidad, focusing on local 'characters', 'easy material for the writer'. ${ }^{11}$ This would be the metier of his first four books of fiction, including his highly acclaimed A House for Mr Biswas (1961), the protagonist of which is based loosely on his beloved father. Coming from the 'enclosed life' of an extended rural Indo-Trinidadian family, 'the disintegrating world of a remembered India', Naipaul 'never ceased to feel a stranger' in Port of Spain after his family's move there. His sense of living on the periphery of a dominant black colonial culture in Port of Spain and later of a dominant white English culture is figured as inhabiting a 'kind of limbo', as an existential homelessness in relation to elusive community. ${ }^{12}$ In this English 'limbo' 'he suffered periods of deep depression and anxiety, even once attempting to gas himself'.$^{13}$ 'I saw people of other groups from the outside; school friendships were left behind at school or in the street. I had no proper understanding of where I was, and really never had the time to find out', he writes of Port of Spain. ${ }^{14}$ Black characters, for instance, Man-man or B. Wordsworth in Miguel Street (1959), are part of the theatricality of communal street life. ${ }^{15}$

To achieve mass appeal with an English audience as a regional West Indian writer, Naipaul suggests in 1958, he would need to supplement writing skill with a few thematic and structural 'devices': 'Sex'; writing a narrative around 'an English or American character' in a Caribbean setting; and 'Race'. His horror at being categorised as the 'West Indian' author of Guerillas might be related to the fact that it does have these 
stock narrative motors of the popular fiction he so despises, including a 'quick-to-strip' female protagonist. While anathematising all of these mechanisms, Naipaul deals with 'Race' in most detail. He finds 'the race issue is too complicated to be dealt with at best-seller, black-and-white level', especially after his time in England. He worries that such 'stories of oppression and humiliation' with their mandatory 'clear oppressors and clear oppressed' may pander to an audience's 'sadistic pleasure', its 'vicarious sense of power'. He usefully raises the question whether a British tabloid audience of the 1950s would necessarily identify with the victim rather than the perpetrator of racial discrimination. His own point of identification is problematic, he states, because of his Indian heritage, his origins in 'an easy-going multi-racial society', and his awareness that racialised conflict can also take the form of black-onblack violence as in the persecution of Tamil people in the then Ceylon. ${ }^{16}$

In The Enigma of Arrival (1987), the narrator of which Naipaul acknowledges to be an autobiographical figure, ${ }^{17}$ he points to a more primal character formation which has shaped his handling of conflict: 'The fear of extinction which I had developed as a child had partly to do with this: the fear of being swallowed up or extinguished by the simplicity of one side or the other, my side or the side that wasn't mine'. ${ }^{18}$ Naipaul's use of evolutionary discourse, here, is telling: it implies a belief that he can make himself fitter in relation to this threat by transcending clear-cut loyalties and causes. Naipaul's unwillingness to hone his sense of imperialism as an analytic category is related, he suggests in 1998, to his resistance to simplifications: he 'grew up with this idea that it was important to look inwards and not always define an external enemy ... We must examine ourselves, examine our own weaknesses' ${ }^{\prime}{ }^{19}$

'Tell me who to kill' in In a Free State (1971) might be read as a story à thèse about Naipaul's sense of the complicatedness of the 'race issue' in England of the 1950s and 1960s. The unnamed first-person narrator of the story, a Hindu from a West Indian island, attends the wedding of his brother Dayo and a white woman. He has lived in England for eight years. Three years before the wedding he has apparently had a breakdown and responded to racist bullying by 'young English louts' in his roti-and-curry shop, ${ }^{20}$ possibly killing one or some of them. He attends the wedding with a white friend Frank, a protector figure. Frank wants always to draw the narrator out about the racial discrimination he has experienced from white people, reducing his experience of England to a series of insults culminating in the breakdown, and his humanity to the fact of racialised difference, 'darkness ${ }^{21}{ }^{21}$ For Frank the narrator's life before his arrival in England is a tabula rasa; the narrator's enemy is external. The narrator, reflecting on his life, realises that Frank's positioning of him as a 'weak' victim ${ }^{22}$ 


\section{S. NAIPAUL}

allows him the pleasure and strength of the homoerotically charged protector role. For Frank the role is the site of his spiritual war against English racism.

The narrator's description of himself as having 'work[ed] like a man in blinkers' in England to support his brother and draw strength from his savings has a wider application to his experience. He has characteristically repressed his anger and humiliation at discrimination, because to focus on this would be 'opening up manholes for' him 'to fall in'. ${ }^{23}$ The metaphor implies castration anxiety. His breakdown has also been scripted by a series of humiliations dating back to the extended family dynamics of his childhood in the West Indies, the protector role he has assumed in relation to his brother (and his brother's abuse of it), a fetishisation of the prospect of Dayo's move via education into a professional class, growing out of touch with his own human needs while, 'donkey'-like, working two jobs, ${ }^{24}$ a poor business decision in opening the shop, and anxieties around changed financial status. It illustrates in part Naipaul's more general proposition that 'the colonial setting ... reduces people to work machines, encourages them to compete as such, strips them of personality'. ${ }^{25}$ England becomes for the narrator a space of decay and death, and he can only read Dayo's marriage to a white woman as a social death. Hollywood B-movies consumed while growing up in the West Indies are a crucial reference point for the narrator. In The Middle Passage Naipaul associates this kind of 'second-rate' cinematic influence with 'minds' that 'are rigidly closed'; this is, for him, a critical sign of 'modernity' in Trinidad. ${ }^{26} \mathrm{~A}$ template drawn from a scene in Alfred Hitchcock's film Rope (1948) continues to function for the narrator as a screen memory for the scene of his violence in his shop.

Naipaul's authorial voice in 'Tell me who to kill' is compassionate towards the narrator and his dilemma that he cannot identify a clearcut enemy responsible for his despair; the sympathy is also grounded in a protective rescue of the narrator from Frank's kind of simplicities. The narrator's stylised patois enriches his humanity; elsewhere, as in The Middle Passage and Guerillas, Naipaul's citation of ungrammatical English and patois serves a mocking function.

In the early stages of his career Naipaul is resistant to his sense of how the 'West Indian writer' is recognised in Britain and restrictive expectations of his or her work and approaches to sex, the exotic, and race relations. He refuses to commodify his writing to meet these expectations, grounded as they are in porno-tropic fantasies of the colonial and ex-colonial world as a site on which 'forbidden sexual desires and fears' might be projected, ${ }^{27}$ and, as he strives to demonstrate, in reductive understandings of the complexity of race relations and of the humanity of the victims of racism. 


\section{Extraregional English subjects}

In Reading 4 Writing (2000) Naipaul acknowledges that in his early years he had not found the 'imaginative key', what he calls elsewhere the 'human experience, the literary experience ${ }^{28}$ to comprehend fully 'English and European fiction'. ${ }^{29}$ In 'London' he writes that he knew 'little about England', the intricacies of life there being kept 'behind closed doors'. 'I have met many people but I know them only in official attitudes - the drink, the interview, the meal. I have a few friends. But this gives me only a superficial knowledge of the country and in order to write fiction it is necessary to know so much: we are not all brothers under the skin.' The public/private dichotomy in English culture, and in London specifically, operates as a barrier to 'communal pleasures' and interaction, a 'barrier of self-consciousness'. This threatens 'sterility' for him..$^{30}$ His sense of vulnerability is perhaps heightened by his growing sense that he could not 'make a living' as a writer 'by being regional'. ${ }^{31}$ In The Enigma of Arrival the narrator notes with some chagrin that he had in the 1950s passed up an important theme, the 'flotsam of Europe' in London boarding houses after the war, 'the beginning of that great movement of peoples that was to take place in the second half of the twentieth century ... These people's principal possessions were their stories, and their stories spilled easily out of them. But I noted nothing down. I asked no questions. I took them all for granted, looked beyond them' ${ }^{32}$

'Fiction works best in a confined moral and cultural area, where the rules are generally known; and in that confined area it deals best with things - emotions, impulses, moral anxieties - that would be unseizable or incomplete in other literary forms', Naipaul insists. ${ }^{33}$ He would return in his fiction set in England or containing sojourns in England on the parts of his protagonists to such confined areas: the communal intimacies and shifting loyalties of boarding houses; England in the late 1940s and 1950s; little Englandism; the making of the black prophet in the 1960s and 1970s; the constrained lives of male immigrants whose search for community, acceptance and masculine reassurance resolves itself illusively and elusively into sex; the country manor and cottage; and the vocation of writing.

The first of Naipaul's novels with an English setting and English characters is Mr Stone and the Knights Companion (1964), usually regarded as his 'attempt to escape from being regarded as a regional writer' ${ }^{34}$ Naipaul develops a searching critique of little Englandism. The librarian protagonist Mr Stone is the epitome of a little Englandism nearing the end of its working life, and reflecting anxiously on its achievements. His anxieties are shaped by pressures on his everyday 


\section{S. NAIPAUL}

white masculinity. Alison Light argues that inter-war little Englandism was a 'conservative modernity', characterised by 'a move away from formerly heroic and officially masculine public rhetorics of national destiny and from a dynamic and missionary view of the Victorian and Edwardian middle classes in "Great Britain" to an Englishness at once less imperial and more inward-looking, more domestic and more private'. It valued 'the quiet life', the 'known and the familiar', the 'nice, decent'. ${ }^{35}$ At the opening of the novel Mr Stone's domestic territorialism, and his familiar comfort with 'slow decay' and 'bulky nineteen-thirty furniture', is affronted by the presence of a black tomcat in his garden and home. Mr Stone is fixated on traces of its 'obscene scuttlings and dredgings and buryings' ${ }^{36}$ Business involving the cat, associated with newcomers to the neighbourhood, may be read as a sign of bachelor Mr Stone's sexual anxiety as he approaches retirement age. It might also, however, be read as a sign of his anxiety about the permissive encroachment of the foreign in his corner of England.

He seeks to manage his sexual anxiety through a prospect of white regeneration, which is, however, short-lived. He marries Margaret Springer, when, symbolically, a tree in view of his back window has 'swollen' buds and 'in sunshine were like points of white'. Margaret introduces a 'new and alien mustiness' into his home and a tigerskin, seemingly a family heirloom, which exacerbate his sense of masculine inadequacy. ${ }^{37}$ 'The "odor di femina" becomes odious, nauseous', Michèle Montrelay argues, 'because it threatens to undo the achievements of repression and sublimation, threatens to return the subject to the powerlessness, intensity and anxiety of an immediate, unmediated connection with the body of the mother. ${ }^{\prime 38}$ The tigerskin is a trophy of imperial masculinity, signalled in the photograph of an 'English cavalry officer', with 'one hand caressing a rifle laid neatly across his thighs', and a 'highly polished boot' on the chest of a dead tiger. In the background are 'three sorrowful, top-heavily turbanned Indians, beaters or bearers or whatever they were'. ${ }^{39}$

On a belated honeymoon in Cornwall Mr Stone experiences a shattering and emasculating moment of 'white void', ${ }^{40}$ 'enveloped' in smoke which robbed him and Margaret 'of earth and reality', him of 'judgment, of the will to act'. ${ }^{41}$ The experience prompts him to develop a welfare scheme for retired employees of his company Excal which will rescue them from an effeminising passivity in retirement and the unremitting 'confinement of family relationships', that is, by women. ${ }^{42}$ While in the days of the Knights Companion scheme he does accommodate himself to the cat's presence in the neighbourhood and its symbolic promise of spring, it is as observer, a distance which comes to signify to him 'his emptiness and the darkness to come' ${ }^{43}$ 


\section{SUE THOMAS}

Stone's foil is the younger Mr Whymper, the Public Relations Officer at Excal, who represents the more aggressive and dynamic masculinity of late 1950s and early 1960s British consumer capitalism. The medieval trappings Whymper gives Stone's welfare scheme mask its efficacy as a contemporary vehicle for marketing and for the enmeshing of Whymper's masculine individualism with consumer capitalism. ${ }^{44}$ Whymper is more overtly and casually xenophobic, racist and misogynistic than Stone. In general non-white people in England register in Stone's consciousness as faces in crowds in localised parts of London (Earl's Court, the streets around the city office, Brixton) and as objects of racist address, for example, by street campaigners for the British National Party. Whymper's sexual adventurousness marks him as a member of a newer permissive generation. His name implies, through allusion to T. S. Eliot's 'The hollow men', that his values will be 'the way the world ends'. ${ }^{45}$

Stone's illumination at the end of the novel that all is flesh, 'man's own frailty and corruptibility', and that triumph over this mocking, feminised nature lies in 'destruction' - the imposition of masculinised will on it - is undercut by his reaction to a young black cat. After exhilaratingly re-energising his sense of masculinity with this 'possibility' of triumph, he realises when his response to the presence of the cat in his home shifts from 'fear' through 'guilt into love' that he was 'no destroyer'. ${ }^{46}$ 'Between the idea/And the reality', 'Between the potency/ and the existence' falls the shadow of his desire for the 'calm' of little Englandism's 'sexual and social economies' ${ }^{47}$ Appeasing this desire has become habitual.

Becoming 'extraregional' for Naipaul has entailed not just a broadening of his range of literary subjects as in $\mathrm{Mr}$ Stone and the Knights Companion; it has also involved a more active dissociation of himself from West Indian communities in England and social and political developments within them. Winston James has highlighted the ways in which racial categorisation in Britain after 1945 operated on a black/white binary, and non-white West Indian immigrants from cultures with a more elaborate and graduated 'pigmentocracy' or shade hierarchy would find themselves interpellated as black. ${ }^{48}$ Indo-Caribbeans would also be called black. ${ }^{49}$ James argues that this epistemic violence has had a productive political effect in developing a pan-black consciousness that might be mobilised against the racism of the dominant culture. He draws attention, too, to a process of Pan-Caribbeanisation: the development of a sense of a regional rather than island or national identity. He attributes this, in part, to British indifference to diversity of colonial or national origins (West Indians generally being homogenised as Jamaican) and island chauvinism, as well as to community-building abroad. Naipaul is 


\section{S. NAIPAUL}

scathing about a pigmentocracy among black people which he reads as a sign of internalised racial inferiority that keeps whiteness as a desired norm: 'Pursuing the Christian-Hellenic tradition, the West Indian accepted his blackness as his guilt, and divided people into the white, fusty, musty, dusty, tea, coffee, cocoa, light black, black, dark black'. ${ }^{50}$ Naipaul has resisted the process of Pan-Caribbeanisation. 'I have nothing in common with people from Jamaica', he comments in 1968. 'Or the other islands for that matter. ${ }^{51}$ More pointedly he has abjured being interpellated as black (preferring the terms Indian or Asiatic). ${ }^{52}$ This move has two historical dimensions. First, he is refusing the black/white binary of British racism that will not accommodate his West Indian Indian heritage. Kobena Mercer explains, too, that especially in the 1980s, the derogatory sign black 'was dis-articulated out of its naturalised [racist] meaning and reference, and re-articulated into an alternative chain of signification in which it became a sign of solidarity among Asian, African and Caribbean peoples. As a sign of political rather than genetic identity, blackness was reappropriated out of one discursive system and rearticulated into another. ${ }^{153}$ In distancing himself from this emerging solidarity, Naipaul reclaims a genetic identity.

Naipaul also points out in 1968 that he was not part of a community of West Indian writers in London: 'We don't have anything in common, you see'. 'I used to read a lot of West Indian novels until 1956. Since then I have stopped really. This is because they have stopped feeding me. It is really hard to read books that don't feed me. ${ }^{54}$ This, of course, feeds his fantasy of being a self-made writer; again, as in double-edged comments like 'I have grown out of Trinidad', ${ }^{55}$ his acerbic relation to the West Indies is represented as a sign of maturity. Naipaul tends to praise in West Indian novels what confirms his world-view and to interpret them through it. For instance, his assessment of Jean Rhys in 1971, important for placing her as West Indian, emphasises the senses of exile and the psychological shipwreck of 'dependence and defeat', the 'woman's half-world' of her protagonists. He commends Rhys for being 'above causes'. ${ }^{56}$

He responds appreciatively in her work to what is a major thematic in his own writing - the displaced colonial subject in England - handled by him in both deeply empathetic and satirical ways. The fear of shipwreck and a sense of being adrift had been leitmotifs of The Mimic Men (1967). Ralph Singh's journeys from the fictive West Indian island of Isabella to London, energised at first by colonial myths of place, are journeys to two-dimensionality - the parts of 'the dandy, the extravagant colonial, indifferent to scholarship' and of the sexualised child to Lady Stella - which like his sexual adventures with 'anonymous flesh' take him 'deeper into emptiness'. In England he finds himself injured into 
feeling 'spectral, disintegrating, pointless, fluid'. ${ }^{57}$ Naipaul reinflects aspects of this topos in Half a Life. Willie Chandran's journey from India to London to an unnamed African colony (recognisably Mozambique) is also a progressive movement to dependence and defeat. His anxieties centre on emasculation and inauthenticity. His 'half' life is one characterised by hiding. For example, as a child he revises European stories movingly, yet obliquely, to accuse his parents of emotional neglect and violence. Pursuing a writing career in England he manufactures fiction from European sources, and because of his skin colour and Indian name, his work is assumed to be authentically Indian.

Naipaul's decision in the 1960s to embrace an extraregional identity as a writer was produced by economic considerations, a determination in the face of interpretative difficulties to broaden his range to include stringent treatments of England and the English, and a pointed disssociation of himself from forms of racist address and racial and PanCaribbean solidarity. As a writer of fiction and criticism he is, though, appreciative of the personal and psychological costs of displacement and exile from community for colonial subjects in England.

\section{The political fray of the 1960 s}

Naipaul observes of himself in 1958: 'after eight years here I find I have, without effort, achieved the Buddhist ideal of non-attachment. I am never disturbed by national or international issues. I do not sign petitions. I do not vote. I do not march. And I never cease to feel that this lack of interest is all wrong. I want to be involved, to be touched even by some of the prevailing anger. ${ }^{58}$ In An Area of Darkness (1964) he attributes this to an Indian 'philosophy of despair, leading to passivity, detachment, acceptance' which had allowed him to 'withdraw completely from nationality and loyalties except to persons; it had made me content to be myself alone, my work, my name (the last two so very different from the first); it had convinced me that every man was an island, and taught me to shield all that I knew to be good and pure within myself from the corruption of causes'.$^{59}$ By the mid-1960s, however, Naipaul is 'touched' by his 'anger' at social change.

Naipaul's metaphor for social change in Trinidad and England becomes the proletariat; his well-known attack in 2000 on Tony Blair's Labour government and what he perceives to be its anti-elitist programme uses a similar metaphor of the plebeian, which perhaps carries more connotations of vulgarity. ${ }^{60} \mathrm{He}$ insists to Derek Walcott in 1964 that a 'sinister' process of proletarianisation has eroded structures of 'aspiration' and the animation of culture by the spirit. In Trinidad 'aspiration has been dropped ... the manners of the proletariat have infil- 


\section{S. NAIPAUL}

trated the rest of society'. In England the rise of popular racism manifested in Conservative Peter Griffiths's electoral win in Smethwick in 1964 is a key sign of proletarianisation. ${ }^{61}$ Stuart Hall argues that Griffiths's victory was 'a turning point in the history of British racism': 'the first moment when racism is appropriated into the official policy and programme of a major political party and legitimated as the basis of an electoral appeal, specifically addressed to the popular white classes. Here is the beginning of racism as an element in the official politics of British populism - racism in a structured and "legitimate" form". ${ }^{62}$ Institutionalised popular racism, Naipaul insists, 'is how a civilisation dies'. Anti-Nazism and anti-apartheid, he declares, are 'good causes', even if organised political activism is anathema to him personally. ${ }^{63}$ Ethnocentrism as a practice of pervasive racism is not targetted by Naipaul in the same vein.

In his essay 'What's wrong with being a snob?' (1967) Naipaul links the degrading proletarianisation of England - emblematically the 'miniman in his mini-car' - with a crisis of liberalism. ${ }^{64}$ Naipaul attacks under the umbrella of proletarianisation the discourse of classlessness, the rise of the welfare state, changing men's fashions, pop musicians as a 'cause for national pride', capitalist consumerism, popular racism, failure of political leadership on the issue of racism, and in the field of the novel 'pretentious pornography and sadism'. 'In the hysteria of self-congratulation, the new greed [of "a booming capitalist society"] expressed itself most hideously', he angrily laments, 'in the persecution of immigrants from the former Empire. Yesterday's slogan on the wall - SEND NIGGERS HOME - was embodied in today's White Paper on limiting immigration.' This is a pointed attack on the repatriation provisions of the August 1965 White Paper issued by the Labour Government; it might also extend to the proposed cut in work-vouchers and stricter controls on dependent relatives. ${ }^{65}$ In depicting Naipaul as an anglophile 'patriotic' racist Rob Nixon overlooks his critiques of the institutionalisation of racism both in this essay and elsewhere ${ }^{66}$ Naipaul urges that the 'romance of the "classless" new society is' being 'ceaselessly offered as compensation' for 'social' and 'economic' 'decay'. He advocates a snobbish 'recognition' of personal and cultural 'difference' from the 'low' as a basis for a renovated civilising mission. As liberalism is brought into 'disrepute' through an unthinking endorsement of a universal humanity, he worries that, 'in the confusion, the liberal principle itself might be totally submerged in weakness, defeat. And fear ${ }^{\prime}{ }^{67}$

There is incoherence in Naipaul's panic over the decay he attributes to the proletarianisation that is at its most visible in the metropolis. It is perhaps for him an unmanageably diffuse area for fictional scrutiny. His most compelling meditation on decay is The Enigma of Arrival, a novel 


\section{SUE THOMAS}

which Frank Kermode notes 'is set in a part of rural England that doesn't count racism or colonialism among its most pressing problems' ${ }^{\prime}{ }^{68}$

As well as proletarianisation, the rise of black consciousness and Black Power movements during the 1960s disturbed Naipaul. Implicitly assigning himself rationality and authentic knowledge, he interprets both as symptoms of racial hysteria and inauthenticity. For Naipaul Black Power is an 'infection' carried from the United States, ${ }^{69}$ characterised by catchcries and ' $[\mathrm{b}]$ orrowed words'. The critiques of the materiality of the lives of black people made by 'the spokesmen for Black Power' offer 'sharp analysis of black degradation'; Naipaul is more scathing about 'Black Power as rage, drama and style', his perception of its 'undermining' of multi-racial politics, and its appeal to popular 'apocalyptic' expectations. ${ }^{70}$ In 'Michael X and the Black Power killings in Trinidad' Naipaul asserts that Michael de Freitas, also known as Michael X and Michael Abdul Malik, 'passed' as 'a Negro' in London. ${ }^{71}$ Naipaul draws on 'local knowledge' to fix Malik as a 'red', a person of mixed African and Portuguese ancestry, and hence a commodified fraud: 'Malik's Negro was, in fact, a grotesque: not American, not West Indian, but an American caricatured by a red man from Trinidad for a British audience' ${ }^{72}$ Naipaul seems to take a grim pleasure in repeating sexist insults relating to miscegenation reportedly levelled at Malik's mother. Malik would become the basis for Jimmy Ahmed in Guerillas; aspects of Percy Cato's career in Half a Life also replicate an early phase of de Freitas's life in England.

Naipaul is harshly critical in Guerillas of the sectors of English society responsible for the making of Jimmy Ahmed: liberals for whom the demonstration and the political meeting are a diversion before tea; those on 'Right and Left' for whom 'race' is a 'topic of entertainment' ${ }^{\prime 73}$ women who use a black man as a 'plaything', a 'playboy'; the sexually permissive woman, 'adrift, enervated, her dissatisfactions vague'. Jimmy's writing of his desire for Englishwoman Jane, the type of the permissive woman, in the idiom of romance fiction demonstrates his psychic dependency on the presumption of the middle-class white woman's fetishisation of his Hakwai (black and Chinese) masculinity. Naipaul, though, is at his most punitive in his representation of Jane,

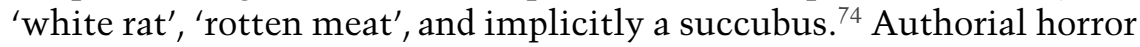
at her is also expressed in her crossing sexually into masculine postures, Jimmy's anal rape of her and her murder.

Naipaul's comment about West Indian books no longer feeding him resonates in the context of his representation of C. L. R. James as flawed prodigy Lebrun in 'On the run', part of his sequence $A$ Way in the World (1994), " a settling of accounts" ... for what he regards as errors of artistic judgment' ${ }^{75}$ In a 1963 review he had praised James's Beyond a 


\section{S. NAIPAUL}

Boundary as 'one of the finest and most finished books to come out of the West Indies, important to England, important to the West Indies'. He concedes there that 'Mr James's career is of particular interest' to him as much for the dissimilarity of their 'backgrounds', as for them both 'speaking the same language' and having 'charmed' themselves 'away from Trinidad'.$^{76}$ The fictive Lebrun, after writing a book that is recognisably The Black Jacobins, has spent a life as a marxist 'revolutionary ... on the run'. He is 'discovered' in 'extreme old age' in England 'as one of the prophets of black revolution, a man whose name didn't appear in the history books, but who for years had worked patiently, had been behind the liberation movements of Africa and the Caribbean'. This 'idea of himself ... had anchored him, had been a kind of livelihood' ${ }^{77}$ which eventually 'began to feed on itself' ${ }^{78}$ Naipaul's story feeds on his earlier work - most pointedly his travel narrative 'The crocodiles of Yamoussoukro'79 - in ways which caution against any easy identification of the narrator as an autobiographical Naipaul figure.

The narrator of the story, a writer by profession, thinks Lebrun is a 'prodigy' of 'rhetoric' and erudition, and is seemingly haunted by the question, 'How, considering where he was born, had he become the man he was? ${ }^{\prime 80}$ The narrator comes to appreciate that Lebrun's marxism, his 'political resolution', is an effort 'to submerge his racial feelings in the universality of his political beliefs', to 'shed one smarting skin' to be 'reborn in another', and that his role as 'black prophet' works to undermine some of his equanimity. ${ }^{81}$ His developing double consciousness of himself as black and British is politically but not personally empowering; instead it returns him to the 'rawness of sensibility' which Naipaul associates with the colonial stranger. ${ }^{82}$ Lebrun becomes more susceptible to the shame of a family heritage that includes an Uncle Tom figure, to anger about cross-racial sex on the part of black women, and to the 'hysteria' of the West Indies, 'expressed most usually in self-satire, jokeyness, fantasy, religious excess, sudden spasms of cruelty'.83 Lebrun's patronym (which means dark man or boy in French) essentialises the anxieties that structure his career in his racial ancestry.

The narrator's refusal of assumptions of political community, his resistance to being seen as 'part of Lebrun's revolution', 'an expression of Lebrun's will', ${ }^{84}$ is realised in his inability to eat the food served to him among Lebrun's admirers. The narrator's ultimate emblem of Lebrun's disillusioning failure to denounce 'a black racial regime ${ }^{\prime 85}$ becomes the 'black diet' - imprisonment without sustenance until death - that the president of Guinea imposes on political enemies identified by Lebrun. As a symbol of savagery it is linked with another alleged local atrocity: human sacrifice to perform a foot-washing ceremony. The narrator asserts that as 'a revolutionary without a base' 


\section{SUE THOMAS}

Lebrun is 'always a failure in one way, in another way fortunate, never having to live with the consequences of his action' ${ }^{86}$

During the 1960s two major strands of Naipaul's response to institutionalised racism and to the rise of black consciousness, as a form of resistance to racial subordination, begin to emerge. Both are historical signs of processes of decolonisation and the diasporic manifestations of it. Naipaul interprets institutionalised racism in England and its former settler colonies as a sign of degenerate proletarianisation and failure of moral leadership, although his comments on this are sparse. In essays and fiction he excoriates aspects of the black consciousness and Black Power movements and the political and social forces in England that abetted their rise there. Naipaul's fictive representation of C. L. R. James as Lebrun in 'On the run' emphasises what he perceives to be the deleterious psychological consequences of racial self-consciousness and the manner in which political investment in pan-black nationalism may undermine the universality of the application of moral standards.

\section{Mythologising a 'universal civilization'}

Naipaul's charge that Lebrun/James was able fortunately to escape measures of responsibility for his acts might in turn be levelled at himself, an eloquent conservative who embraces a sense of existential national homelessness, travelling with or able to purchase a return ticket home to England. He never has to live fully with the everyday consequences or implications of his acts of representation. The negativity of his commentary on travel destinations and cultures outside what is often termed the First World can feed the prejudices of and recirculate stereotypes for his readers. In a 1979 interview with Elizabeth Hardwick Naipaul says, for instance: 'I do not write for Indians ... who in any case do not read. My work is only possible in a liberal, civilized Western country. It is not possible in primitive societies. ${ }^{187}$ To Tarun J. Tejpal in 1998 he speaks casually of 'writing from India or other retarded or former colonies' ${ }^{88}$ One thinks here, too, of his famous dismissal of the West Indies in The Middle Passage - 'History is built around achievement and creation; and nothing was created in the West Indies' ${ }^{\prime 8}$ As with Black Power, Naipaul represents multiculturalism as a neocolonising import from the United States to Britain. Yet, too, in terms of the clash of civilisations theory through which Naipaul currently interprets world history, it is a policy 'fostered by Islamic groups'. In 2001 he mocks the policy as 'multi-culti', mobilising again, as with his denunciation of Black Power politics, a belittling discourse of redemptive desire and unreason, and treats it as a contributing factor to England's current 'cultural mess'. For him the key sign of the deficiency 


\section{S. NAIPAUL}

of the policy is the 'cover[ed]' up Islamic woman. She represents 'oppressive regimes', an 'oppressive faith' which 'hates humanity', 'old customs' which have 'kept' her community 'down'. Her veil becomes a site of cross-generational contagion: her children are bearers of religious fundamentalism. Some, Naipaul insists, despite being British nationals, 'become terrorists in foreign lands' - Yemen, Bosnia, Kashmir, 'places like that'. The stubborn spectacle of the veiled woman in Britain is a symbol of missionary inertia on the part of the more enlightened..$^{90}$ The tone of such judgements amply exhibits the 'authorial absolutism' which Homi Bhabha discerns in Naipaul's 'large-scale civilizational arguments' of the variety 'Certain societies are quite limited. It is difficult anyhow to be profound about them. ${ }^{.91}$ It is more often in the imaginative reaches afforded by fiction that Naipaul is able to transcend the simplicities of his side.

Naipaul might define his more recent work as an elaboration of the value of a 'universal civilization', a concept that he begins to articulate explicitly around 1980: 'the idea of the individual, responsibility, choice, the life of the intellect, the idea of vocation and perfectibility and achievement'. 'It is the civilization, first of all, which gave me the idea of the writing vocation', he explains. 'It is the civilization in which I have been able to practice my vocation as a writer ... [M]y movement within this civilization has been from the periphery to the centre.' This civilisation is not synonymous with the colonialism of his upbringing, but rather, he insists in 1991, a liberal, evolutionary development of it, which is in the process of transcending 'racialism' and working 'to accommodate the rest of the world, and all the currents of that world's thought ${ }^{\prime} .^{92}$ This accommodation involves in Britain a respect for 'human rights and human needs'. ${ }^{93}$ As Jan Pettman points out, 'Human rights have long been associated with a western, liberal and individualistic approach to rights' ${ }^{94}$ Naipaul consciously represents his ideal of the individual as being grounded in 'metropolitan assumptions about society: the availability of a wider learning, an idea of history, a concern with self-knowledge'.$^{95}$

Naipaul writes of Conrad that rather than 'discover' himself and his 'world' through writing, his 'character had been formed' before he 'settled down to write'. He implicitly associates this with Conrad's propensity to cite 'portable truths, as it were, that can sometimes be rendered as aphorisms - and work through to their demonstration'. Giving Conrad's story 'The return' as an example of the method, he notes that 'the people remain abstractions' ${ }^{96}$ Naipaul's discourse of civilisation is replete with 'portable truths', a vocabulary of the "'barbarous", "primitive", "tribal", "static", and "simple" societies, "world civilization", "bush", "philistine", the "colonial", the "whole man", "security", "sentimentality", 
"parasitic", "borrowed culture", and "mimicry". Reiteratively, and in combination', as Nixon notes, 'these terms of reference become a compressed expression of Naipaul's Weltanschauung'. ${ }^{97}$ These 'truths' profoundly reduce the humanity of the people and characters about whom Naipaul writes, producing them as abstractions, bearers of cultural and often racialised essences. The method is one that justifies Akeel Bilgrami's observation that Naipaul's 'cultural commentary' on the nonWest 'typically combined an effortless contempt with a cultivated ignorance of the historical and the institutional sources of a culture's surface presentation' ${ }^{98}$ The meticulousness of Naipaul's detailing of that presentation - 'the sketches of fellow travellers, of the daily routines, the vessels, living quarters and facilities, food, drink, recreations, chance and deliberate encounters, conversations engaged in or, just as often, overheard' - nonetheless, as Mustafa suggests, 'establishes an aura of verisimilitude'. ${ }^{99}$ The specificity of local detail belies the grounding of his broader cultural observations in formulaic, portable truths.

Naipaul's travel writing, advocacy of the standards of a universal civilisation, and casual cultural commentary in interviews illustrate amply the reactionary conservatism of his politics of decolonisation. His view of historical progress is more pessimistic than that of C. L. R. James, whose position is outlined by Bill Schwarz and Catherine Hall in this volume. Naipaul's attitude to a lived British liberalism is markedly ambivalent. He is fierce both in his denunciations of liberal support for Black Power during the 1960s and 1970s and for multiculturalism as a policy of national belonging since the 1980s, and in his defence of the liberal principles integral to his ideal of a universal civilisation.

\section{'[S]hed[ding] the nerves of being a stranger'}

After a year spent in India in the early 1960s, Naipaul found himself again in London alienated by the prospective domestication of his difference - home in a 'separate warm' cell - which abandoned him to 'emptiness', a 'feeling of being physically lost', 100 a return to a being in which he became his 'flat', his 'desk', his 'name'. The dream of the metropolis, a 'mythical' land, was unravelling. ${ }^{101}$ This demystification is a central theme of The Mimic Men in which Ralph Singh, the firstperson narrator, reconstructs his first sojourn in London, 'this dying mechanized city' $^{102}$ In moving from London to the cottage on the manor, the autobiographical narrator of The Enigma of Arrival had desired 'to strip' his 'life down' through a 'spirit of withdrawal', to accommodate himself to the style of the cottage, altering 'as little as possible' there. ${ }^{103}$

The Enigma of Arrival is structured around a thematic of looking 


\section{S. NAIPAUL}

and being looked at, and a contrast between two writer figures, the narrator and his fictive landlord, who both suffer from nervous illness. The narrator mentions repeatedly his raw nerves of the stranger, of the colonial in England. His experience of rural England - solitude, the steady measure of walking, isolation, 'surrender' to his 'way of looking', and indulgence of his 'linguistic or historical fantasies' - enables him 'to shed the nerves of being a stranger' ${ }^{104}$ The nerves are metonymic of his epidermalised racial difference, the 'smarting skin' he observes of Lebrun. In An Area of Darkness Naipaul acknowledges that 'recognition' of his Indian 'difference was necessary to' him. ${ }^{105}$ The narrator of The Enigma of Arrival, however, desires not to be seen by his landlord; the landlord recognises him as fellow artist by sending gifts of his work through an intermediary. The landlord's representations of racial difference are grounded, the narrator insists, in 'sensual' romances of empire from 'the days of imperial glory', 106 and a 'joke knowledge of the world ... fed by the manor and the grounds', ${ }^{107}$ emblems of 'England, wealth, empire, the idea of glory, material satiety, a very great security'. ${ }^{108}$ In them the narrator discerns a nostalgic fascination with decadence and homoerotic fantasies of foreign men. The illness of the landlord, accidia, resonates with 1920s literary representations of English degeneracy. The landlord's relation to his place in England after the second world war is compressed in his claustration, a possession of the manor through panoramic vision from the country house that is his sign of ownership, the 'physical helplessness' which Sara Suleri reads 'as a synecdoche for imperial devolution', 109 and the parasitic destructiveness of the ivy he orders should not be cut. Here Naipaul inverts the trope of parasitism that often figures the postwar immigrant's relation to the British state in racist discourse. The narrator's desire for invisibility in relation to the landlord marks a desire not to be fixed by or to have recognition as an artist tainted by a stereotyping and potentially homoerotic gaze.

Through familiarity and minute analysis of the disruption of simple myths of rural Englishness by more elemental complexities of decay and renewal, the narrator's gaze in the novel assumes renovated features of what Mary Louise Pratt terms 'Victorian discovery rhetoric' attached to a 'monarch-of-all-I-survey scene'. Pratt characterises Victorian discovery rhetoric as aestheticising the landscape, often ordering through the genre of painting - 'large and small, back and front'; conferring 'density of meaning' through 'adjectival modifiers'; and developing a relation of mastery 'between the seer and the seen'. ${ }^{110} \mathrm{~A}$ formative English literary and artistic tradition, a remembered Trinidad, and his vocation are the homes which act as the narrator's reference points in his self-consciously precise dramatisation of ways of seeing and their relation to being. His 


\section{SUE THOMAS}

meditations secure an increasing analytic and philosophical mastery over a feminised nature that threatens man's achievements with ruin and decay.

Naipaul has modelled himself as writer in a conservative mould: dedicated to mastery over craft, close moral examination, ambition and nature; affecting political disinterest in creative prose; and wilfully transcending the vulgarities of popular cultures (including their perceived racisms), and the anxieties that have beset his journey to the centre of English culture. Arguably, and I pointedly echo here Naipaul's representation of Lebrun in 'On the run', his artistic resolution is an effort to submerge his racial feelings in the perceived universality of his transcendent and scrupulous vision of the Olympian writer. Naipaul's accounts of being formatively placed on peripheries of community in Port of Spain and England are permeated by a sense of loss: loss of material as a writer; and, more faintly, of a sense of civic identity that might confer substance outside vocation. The sense of civic displacement that has haunted his journey movingly informs an important and finely nuanced thread in his fiction: the sense of unease and exile the colonial subject may experience in England. This is a pervasive preoccupation of West Indian writers who treat Caribbean immigrant and expatriate experience in Britain. Naipaul has pointedly dissociated himself from West Indian social and political communities and their late modern histories both in the Caribbean and in Europe, preferring instead to claim an extraregional identity and scope and more recently to champion the ideals of a prized 'universal civilization'. His reputation as a reactionary in relation to the politics of decolonisation and race is certainly merited, but Said's and Nixon's condemnations of that politics, which are typical of those of his detractors, are too sweeping. Naipaul's representations of England and the English do not uniformly indulge a patriotic racism and imperial nostalgia or play to persistent racial stereotypes of non-white peoples in England. His conservatism, too, is characterised by deeply conflicted attitudes to liberal principles with respect to racial issues and histories.

\section{Notes}

1 V. S. Naipaul, 'Our universal civilization', New York Review of Books, 31 January 1991, p. 22.

2 Naipaul speaks of having 'made' himself a writer by the age of twenty-five in Reading \&) Writing: a personal account (New York: New York Review of Books, 2000), p. 19.

3 Diana Athill, Stet: a memoir (London: Granta, 2000), p. 232.

4 Mel Gussow, 'V. S. Naipaul: "It is out of this violence I've always written"', New York Times, 16 September 1984.

5 V. S. Naipaul, Half a Life: a novel (London: Picador, 2001). 


\section{S. NAIPAUL}

6 'Nobel Prize for Literature 2001 - Press Release'.

7 Edward Said, 'Intellectuals in the post-colonial world', Salmagundi, 70:1 (1986), p. 53.

8 V. S. Naipaul, 'London' (1958), in his The Overcrowded Barracoon and Other Articles (Harmondsworth: Penguin, 1976; first published 1972), p. 9.

9 Naipaul, Reading $\uplus$ Writing, p. 15.

10 V. S. Naipaul, Letters Between a Father and Son (London: Abacus, 2000; first published 1999), p. 313.

11 Naipaul, 'London', p. 10.

12 Naipaul, Reading e) Writing, p. 13; 'Without a place: V. S. Naipaul in conversation with Ian Hamilton', Times Literary Supplement, 30 July 1971, in Feroza Jussawalla (ed.), Conversations with V. S. Naipaul (Jackson: University Press of Mississippi, 1997), p. 15.

13 Stephanie Bunbury, 'An audience with Sir Vidia', Age (Melbourne), 18 August 2001, p. 4.

14 Naipaul, Reading $\uplus$ Writing, pp. 13-15.

15 V. S. Naipaul, Miguel Street (London: André Deutsch, 1959).

16 Naipaul, 'London', pp. 11-12.

17 'The writer, the observer, that is scrupulously myself. The minute other people are in the picture, that is where the fictive element comes in', Naipaul comments in an interview with Mel Gussow, 'The enigma of V. S. Naipaul's search for himself in writing', New York Times, 25 April 1987.

18 Naipaul, The Enigma of Arrival: a novel in five sections (London: Penguin, 1987), p. 140.

19 Tarun J. Tejpal, 'Arrivals and other enigmas: V. S. Naipaul's way in the world', at random magazine, (1998), www.stanford.edu.au/ amitm/naipaul/tejpal.html, p. 3 (accessed August 2001).

20 V. S. Naipaul, 'Tell me who to kill', in his In a Free State (London: André Deutsch, 1971), p. 94 .

21 Naipaul, 'Tell me who to kill', p. 91.

22 Naipaul, 'Tell me who to kill', p. 91.

23 Naipaul, 'Tell me who to kill', p. 91.

24 Naipaul, 'Tell me who to kill', p. 107.

25 V. S. Naipaul, 'A plea for rationality', in I. J. Bahadur Singh (ed.), Indians in the Caribbean (New Delhi: Sterling, 1987), p. 21.

26 V. S. Naipaul, The Middle Passage: impressions of five societies - British, French and Dutch - in the West Indies and South America (London: André Deutsch, 1963), p. 61.

27 Anne McClintock, Imperial Leather: race, gender and sexuality in the colonial contest (New York: Routledge, 1995), p. 22.

28 V. S. Naipaul, Finding the Centre: two narratives (Harmondsworth: Penguin, 1985; first published 1984), p. 10.

29 Naipaul, Reading et Writing, pp. 16 and 19.

30 Naipaul, 'London', pp. 14-17.

31 'Naipaul: an interview with Ewart Rouse', Trinidad Guardian (1968), in Jussawalla, Conversations, p. 10.

32 Naipaul, The Enigma of Arrival, p. 130.

33 Naipaul, Reading 4 Writing, pp. 49-50.

34 John Thieme, The Web of Tradition: uses of allusion in V. S. Naipaul's fiction (Hertford: Dangaroo Press/Hansib Publications, 1987), p. 93.

35 Alison Light, Forever England: femininity, literature and conservatism between the wars (London: Routledge, 1991), pp. 8 and 11-12.

36 V. S. Naipaul, Mr Stone and the Knights Companion (London: André Deutsch, 1963), pp. 22, 42 and 6.

37 Naipaul, Mr Stone, pp. 34 and 41.

38 Summarised by Jane Gallop, The Daughter's Seduction: feminism and psychoanalysis (Ithaca, NY: Cornell University Press, 1982), p. 27. 


\section{SUE THOMAS}

39 Naipaul, Mr Stone, p. 44.

40 Naipaul, Mr Stone, p. 71.

41 Naipaul, Mr Stone, p. 64.

42 Naipaul, Mr Stone, p. 84.

43 Naipaul, Mr Stone, p. 134.

44 Graham Dawson associates medieval knights with pre-capitalist adventure in Soldier Heroes: British adventure, empire and the imagining of masculinities (London: Routledge, 1994), p. 59.

45 T. S. Eliot, 'The hollow men', Selected Poems (London: Faber, 1961), p. 80.

46 Naipaul, Mr Stone, p. 160.

47 Eliot, 'The hollow men', p. 80; Naipaul, Mr Stone, p. 160; Light, Forever England, p. 13.

48 Winston James, 'Migration, racism and identity formation: the Caribbean experience in Britain', in Winston James and Clive Harris (eds), Inside Babylon: the Caribbean diaspora in Britain (London: Verso, 1993), p. 239.

49 James, 'Migration, racism and identity formation', p. 276.

50 Naipaul, The Middle Passage, pp. 67-8.

51 'Naipaul: an interview with Ewart Rouse', in Jussawalla, Conversations, p. 10.

52 Jussawalla, 'Introduction', Conversations, p. iv.

53 Kobena Mercer, 'Back to my routes: a postscript to the 1980s (1990)', in James Procter (ed.), Writing Black Britain 1948-1998: an interdisciplinary anthology (Manchester: Manchester University Press, 2000), p. 288.

54 'Naipaul: an interview with Ewart Rouse', in Jussawalla, Conversations, pp. 10-11.

55 Derek Walcott, 'Interview with V. S. Naipaul', Sunday Guardian (Trinidad), 7 March 1965, in Jussawalla, Conversations, p. 7.

56 V. S. Naipaul, 'Without a dog's chance', review of After Leaving Mr Mackenzie, by Jean Rhys, New York Review of Books, 18 May 1972, pp. 30-1.

57 V. S. Naipaul, The Mimic Men (London: André Deutsch, 1967), pp. 24, 34 and 61.

58 Naipaul, 'London', p. 16.

59 V. S. Naipaul, An Area of Darkness (Harmondsworth: Penguin, 1968; first published 1964), p. 188.

60 He traces the origins of the decay of cultural elitism which 'has destroyed the idea of civilisation in this country' to the 1945-51 Labour governments of Clement Attlee: Fiachra Gibbons, 'It is terrible, this plebeian culture that celebrates itself', Guardian, 11 July 2000.

61 Walcott, 'Interview', pp. 6-7.

62 Stuart Hall, 'Racism and reaction', in Five Views of Multi-Racial Britain: talks on race relations broadcast by $B B C T V$ (London: Commission for Racial Equality, 1978), p. 29.

63 Walcott, 'Interview', p. 8.

64 V. S. Naipaul, 'What's wrong with being a snob?' (1967), in Robert D. Hamner (ed.), Critical Perspectives on V. S. Naipaul (London: Heinemann, 1977), p. 36.

65 See Ann Dummett and Andrew Nicol, Subjects, Citizens, Aliens and Others: nationality and immigration law (London: Weidenfeld and Nicolson, 1990), pp. 194-5.

66 Rob Nixon, London Calling: V. S. Naipaul, postcolonial mandarin (Oxford: Oxford University Press, 1992), p. 47.

67 Naipaul, 'What's wrong with being a snob?', pp. 35-7.

68 Frank Kermode, 'In the garden of the oppressor', review of The Enigma of Arrival, New York Times, 22 March 1987.

69 Naipaul, Overcrowded Barracoon, p. 270.

70 V. S. Naipaul, 'Power?', New York Review of Books (1970), in Overcrowded Barracoon, pp. 269-70.

71 V. S. Naipaul, The Return of Eva Perón with The Killings in Trinidad (Harmondsworth: Penguin, 1981; first published 1980), p. 52.

72 Naipaul, The Return of Eva Perón, p. 37.

73 Naipaul, The Return of Eva Perón, pp. 25 and 29. 


\section{S. NAIPAUL}

74 Naipaul, Guerillas, pp. 26, 48, 90, 60 and 239.

75 Mel Gussow, 'V. S. Naipaul in search of himself: a conversation', New York Times, 24 April 1994.

76 V. S. Naipaul, 'Cricket' (1963), in Overcrowded Barracoon, p. 23.

77 V. S. Naipaul, A Way in the World: a novel (New York: Alfred A. Knopf, 1994), pp. 109-10. The novel was subtitled A sequence in the British edition.

78 Naipaul, A Way in the World, p. 135.

79 The essay is the second of the narratives in Naipaul's Finding the Centre.

80 Naipaul, A Way in the World, p. 117.

81 Naipaul, A Way in the World, pp. 119, 133, 128 and 135.

82 Naipaul, A Way in the World, p. 161.

83 Naipaul, A Way in the World, p. 134.

84 Naipaul, $A$ Way in the World, p. 127.

85 Naipaul, A Way in the World, p. 135.

86 Naipaul, A Way in the World, p. 161.

87 Elizabeth Hardwick, 'Meeting V. S. Naipaul', New York Times Book Review (1979), in Jussawalla, Conversations, p. 45.

88 Teipal, 'Arrival and other enigmas'.

89 Naipaul, The Middle Passage, p. 29.

90 Rachael Kohn, 'India through V. S. Naipaul's eyes', The Spirit of Things, Radio National (Australia), 9 September 2001.

91 Homi Bhabha, 'Naipaul's vernacular cosmopolitans', Chronicle of Higher Education, 26 October 2001.

92 Naipaul, 'Our universal civilization', pp. 22 and 25.

93 Charles Wheeler, "'It's every man for himself" - V. S. Naipaul on India', Listener (1977), in Jussawalla, Conversations, p. 44.

94 Jan Jindy Pettman, Worlding Women: a feminist international politics (Sydney: Allen and Unwin, 1996), p. 210.

95 Naipaul, Reading et Writing, pp. 50-1.

96 V. S. Naipaul, 'Conrad's darkness', New York Review of Books (1974), in Hamner, Critical Perspectives on Naipaul, pp. 61, 63 and 64.

97 Nixon, London Calling, p. 109.

98 Quoted in Chinua Achebe, Home and Exile (Oxford: Oxford University Press, 2000), p. 86.

99 Fawzia Mustafa, V. S. Naipaul (Cambridge: Cambridge University Press, 1995), pp. 77-8.

100 Naipaul, An Area of Darkness, p. 266.

101 Naipaul, An Area of Darkness, p. 42.

102 Naipaul, Mimic Men, p. 97.

103 Naipaul, The Enigma of Arrival, p. 174.

104 Naipaul, The Enigma of Arrival, p. 23.

105 Naipaul, An Area of Darkness, p. 43.

106 Naipaul, The Enigma of Arrival, pp. 192-3.

107 Naipaul, The Enigma of Arrival, p. 253.

108 Naipaul, The Enigma of Arrival, p. 193.

109 Sara Suleri, 'Naipaul's arrival', Yale Journal of Criticism, 2:1 (Fall 1988), p. 46.

110 Mary Louise Pratt, Imperial Eyes: travel writing and transculturation (London: Routledge, 1992), pp. 204-5. 